\title{
Effect of Netting Duration on Ethiopian Pepper Mottle Virus (EPMV) Infection and Aphid Infestation of Hot Pepper (Capsicum annuum L.) in Central Rift Valley Region of Ethiopia
}

\author{
Kumsa Dida ${ }^{1 *}$, Alemayehu Chala ${ }^{2}$ and Ferdu Azerefegne ${ }^{2}$ \\ ${ }^{1}$ College of Agriculture and Natural Resource Management, Jinka University, Ethiopia \\ ${ }^{2}$ College of Agriculture, Hawassa University, Ethiopia
}

\begin{abstract}
Ethiopian pepper mottle virus is one of the major constraints of pepper production in the central rift valley region of Ethiopia. The present study was conducted to determine optimum netting duration for efficient protection of pepper from vector infestation and subsequent viral infection. For this purpose, an experiment was carried out in the central rift valley of Ethiopia (i.e. Meki and Hawassa districts). Data were collected on the number of aphid populations, virus incidence, and pepper growth parameters and yield. Significant variations at $(p<0.01)$ were observed between treatments of the field experiments in terms of aphid infestation, virus incidence and pepper yield. Covering of plots with net for up to 60 or more days after transplanting reduced aphids' population per plant by a greater margin $(61.8 \%-76.9 \%$ in Hawassa, $52.4-67 \%$ in Meki) and virus incidence by $48 \%-60.8 \%$ in Hawassa and $38.6 \%-48.5 \%$ in Meki as compared to the control plots. Total and marketable yields were significantly higher in plots protected by net for up to 60 days or more after transplanting while unmarketable yields were low in those plots. Low virus incidence and aphids' population in plots covered by net up to 60 days after transplanting and longer resulted in increased yields by $44 \%-55 \%$ in Hawassa and $38 \%-$ $49.5 \%$ in Meki as compared to the control plots. Unmarketable yield was positively correlated $(p<0.001)$ with aphids population and virus incidence while total and marketable yields were negatively correlated with aphids population and virus incidence. The results suggest the need to apply control measures at early growth stages to effectively protect pepper plants from aphids and associated viruses.
\end{abstract}

\section{Keywords}

Aphid, Ethiopiapepper mottle virus, Netting duration

\section{Abbreviations}

EPMV: Ethiopian pepper mottle virus; GLM: General Linear Model; YWT: Yellow Water Traps; DAT: Days after transplanting; CMV: Cucumber Mosaic virus

\section{Introduction}

Hot pepper (Capsicums spp.) is one of the main crops belonging to the family Solanaceae and used as fresh, dried or processed products, as vegetables and spices or condiments grown in different parts of the world [1]. The genus Capsicum is the second main vegetable crop of the family after tomato Solanaceae in the world [2].

Hot pepper serves as one of the important sources of food and income to smallholder farmers and as exchange earning commodities [3]. It is important part in the daily diet of most Ethiopian societies. The standard daily utilization of hot pepper by Ethiopian adult is estimated at $15 \mathrm{~g}$, which is higher than most other vegetables [4]. Pepper yields varies signifi- cantly from one region to other region due to several factors such as topography, lack of improved varieties, soil type, wa-

*Corresponding author: Kumsa Dida, College of Agriculture and Natural Resource Management, Jinka University, P.O. Box 165, Jinka, Ethiopia

Accepted: September 14, 2020

Published online: September 16, 2020

Citation: Dida K, Chala A, Azerefegne F (2020) Effect of Netting Duration on Ethiopian Pepper Mottle Virus (EPMV) Infection and Aphid Infestation of Hot Pepper (Capsicum annuum L.) in Central Rift Valley Region of Ethiopia. J Plant Pathol Res 2(1):612

Copyright: (c) 2020 Dida K, et al. This is an open-access article distributed under the terms of the Creative Commons Attribution License, which permits unrestricted use, distribution, and reproduction in any medium, provided the original author and source are credited. 
Citation: Dida K, Chala A, Azerefegne F (2020) Effect of Netting Duration on Ethiopian Pepper Mottle Virus (EPMV) Infection and Aphid Infestation of Hot Pepper (Capsicum annuum L.) in Central Rift Valley Region of Ethiopia. J Plant Pathol Res 2(1):6-12

ter quality, drought, insect pest, diseases, different cultural practices, soil tillage and fertilizer application [5].

Arthropod pests and diseases caused by different fungi, bacteria and viruses are the most important ones [6]. Viral diseases such as EPMV, potyvirus and fungal diseases like powdery mildew, stem and leaf blight, pod bleaching, damping off and bacterial leaf spot have emerged as severe threats to the crop in the foremost producing areas $[7,8]$. Viruses are reported to cause total crop failure in addition to lowering yields and reducing fruit quality [6].

More than $90 \%$ viral disease incidences and absolute crop failure have been reported from various places in Ethiopia $[9,10]$. Relative importance of viruses on pepper is quite erratic across regions, where a few viruses are common to a particular region. Ethiopian pepper mottle virus (EPMV), a potyvirus occurring in diverse or single infection, is the most significant virus in the rift valley and southern parts of Ethiopia $[7,9,10]$. Local and regularly grown varieties such as 'Markofana' are highly susceptible to EPMV and aphids which help as vector to spread this disease $[8,11]$.

Crops and weeds in and around fields may affect the species diversity of vectors and are often potential sources of virus inoculum Tameru, et al. and Atsebeha, et al. $[10,11]$ found several cultivated crops and volunteer plants that influenced the species composition of aphids present on pepper farms. The migratory habits of aphids make them important vectors of plant viruses. Peak aphid flights and the presence of known vectors are often associated with rapid spread of viruses in a particular area. In some case virus incidences are correlated with high numbers of inefficient vectors when the numbers of efficient vectors were low $[11,12]$.

The epidemiology of viruses differ along with localities, time and a factor of local source of inoculum, vector complex involved and how the pretenses of vectors are harmonized with the phenology of the crop [12]. So understanding the epidemiology of aphid-borne viruses is very essential for the development of appropriate management strategies. Barrier crops, mulches and nets are used to decrease virus infection and vector infestation in several non-persistently transmitted plant viruses. For example, netting of okra plants for up to 4-5 weeks reduced the number of jassids and whiteflies as well as virus infection when compared with that of un-netted plants [13]. Therefore, the experiment was under taken to determine the optimum netting duration for efficient protection of hot pepper from aphid's infestation and EPMV infection and to evaluate the effect of EPMV on the yield of hot pepper under different netting durations.

\section{Material and Methods}

\section{Site description}

The netting experiment was conducted at Hawassa and Meki. Hawassa is located between $7^{\circ} 3^{\prime}$ latitude north and $38^{\circ}$ $28^{\prime}$ longitude east at altitude of 1680 meter above sea level. This area is characterized by dry sub humid climate; it has monthly mean minimum and maximum temperature of 10.4 ${ }^{\circ} \mathrm{C}$ and $27.5^{\circ} \mathrm{C}$, respectively and annual rain fall of $900-1300$ $\mathrm{mm}$. Meki is located between $7^{\circ} 58^{\prime}$ latitude north and $38^{\circ} 43^{\prime}$ longitude east at altitude of 1636 meter above sea level. It is has annual rain fall of 500-1159 $\mathrm{mm}$ and minimum and maximum temperature of $12{ }^{\circ} \mathrm{C}$ and $27.5^{\circ} \mathrm{C}$ respectively.

\section{Planting and treatment description}

Seedlings of the pepper variety Marekofana which highly is susceptible to EPMV were raised under a protective cover and sprayed with the systemic insecticide dimethoate (1 liter/ hectar) weekly to restrict aphids that are vector for EPMV. Pepper seedlings were transplanted to the Hawassa university experimental field and commercial farm field at Meki, when they reached a two leaf growth stages. Experimental plots had a size of $2 \mathrm{~m} \times 2 \mathrm{~m}$ each and the spacing between plant and rows were $0.3 \mathrm{~m} \times 0.5 \mathrm{~m}$ respectively. The plots and block were spaced one meter apart. A plot contained four rows and each row had six plants, as a result, there were 24 plants per plot. The experiment was laid out in randomized complete block design (RCBD) with three replications consisting of the following Treatments: T1: No net barrier (control), T2: Pepper covered with net for up to 20 days after transplanting (DAT), T3: Pepper covered with net for up to 40 DAT, T4: Pepper covered with net for up to 60 DAT, T5: Pepper covered with net for up to 80 DAT or until flowering, T6: pepper covered with
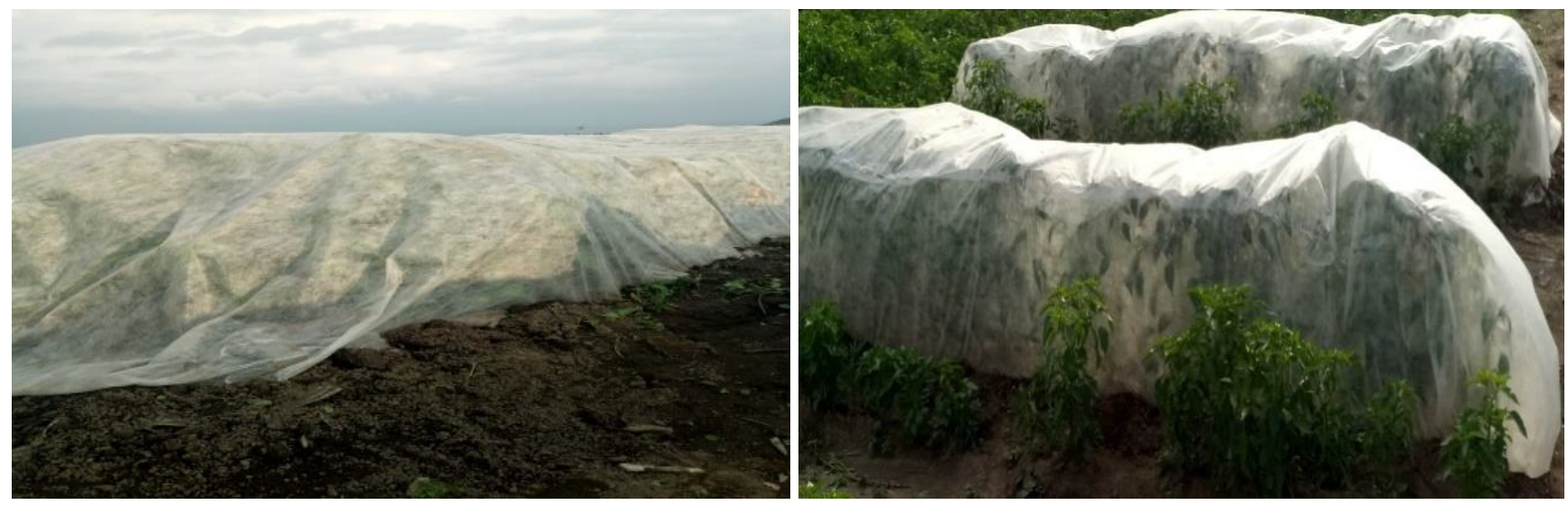

Figure 1: Pepper growing under netting. 
Citation: Dida K, Chala A, Azerefegne F (2020) Effect of Netting Duration on Ethiopian Pepper Mottle Virus (EPMV) Infection and Aphid Infestation of Hot Pepper (Capsicum annuum L.) in Central Rift Valley Region of Ethiopia. J Plant Pathol Res 2(1):6-12

net until harvesting, T7: Weekly spraying of dimethoate $40 \%$ EC (1000 ml/ha), A contact insecticide, applied at seven days interval. Covering of pepper plants was made using a standard nylon net capable of blocking vector infestations (Figure 1). The pepper was grown under irrigation. The recommended rate of DAP ( $200 \mathrm{~kg} / \mathrm{ha})$ and half of the recommended rate of urea $(100 \mathrm{~kg} / \mathrm{ha})$ fertilizers were applied in bands at the time of transplanting. The remaining half rate of urea was applied during active stage of vegetative growth [14]. All other recommended cultural practices were performed uniformly to all plots as per the recommendation.

\section{Data Collection}

\section{Monitoring of aphid populations in experimen- tal field}

Aphids were monitored by using Yellow Water Traps (YWT) that was made from yellow plastic container with size of $10 \times 35 \times 20 \mathrm{~cm}$ (Figure 2). One YWT was placed in the middle of each plot one week after transplanting of pepper plants. The traps were filled with water up to small outlets below the rim. The heights of the traps were adjusted according to the crop canopy. Five milliliter of formaldehyde was added in the water of each trap to keep the aphids intact and prevent birds from drinking the water. Every week, the solution in YWT was changed and trapped aphids were collected until the pepper crop fully matures. The collected aphids were counted according to date of collection and treatments. The data was summarized to investigate the population of aphids in relation to the crop phenology.

\section{Incidence of Ethiopian pepper mottle virus (EPMV)}

Starting 20 days after transplanting, all pepper plants in each plot were visually assessed for the incidence of EPMV infection caused by natural infestation special aphid's infestation. Well established symptoms based evaluation method for EPMV was used for rating of the incidences $[8,15]$. Ethiopia pepper mottle virus incidence on each experimental treatment was recorded by counting number of diseased plants and calculating as the proportion of the diseased plant over the total number of stand count per treatment.

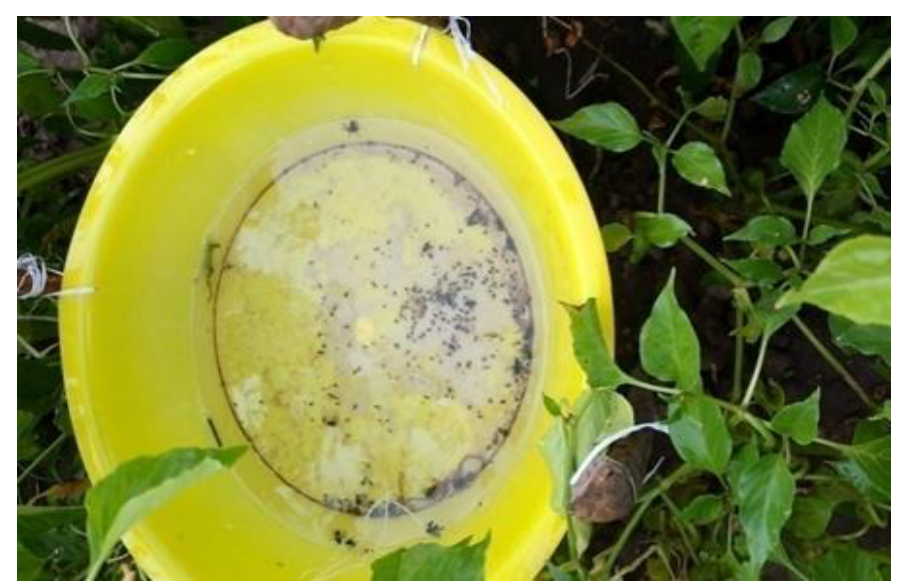

\section{Marketable yield and unmarketable yield}

Pepper pods were harvested from the inner two rows of each plot, and the pods were sorted into marketable and unmarketable pods based on the presence or absence of green mottling, swelling, color, and shape deformation. Weights of marketable, unmarketable, and total fruit were measured.

Marketable yield ( $q / h a)$ : The marketable yield of eight sample plants per plot was determined at harvesting by sorting fruits according to color, shape, shininess, firmness, and size of the fruits. After separation, the weight of marketable fruits were recorded and converted to $\mathrm{q} / \mathrm{ha}$.

Unmarketable yield ( $q / h a)$ : The yield which was obtained by sorting the diseased, discolored, shrunken, shaped and small size, totally unnecessary pod separated from marketable pods were recorded at harvest and converted to $q /$ ha.

Total yield ( $q / h a)$ : Weight of total marketable and unmarketable fruits harvested from each sample plants were recorded and summed up to estimate yield per hectare.

\section{Data Analysis}

Data on aphid populations, viral incidence, and yield were subjected to analysis of variance (ANOVA) using General Linear Model (GLM) procedures of SAS version 9.00 [16]. Whenever treatment differences were significant, the differences among treatment means were compared using LSD test at $5 \%$ level of significance. Correlation analysis was carried out by using proccorr procedure of simple Pearson correlation to assess the relationship between aphid populations, disease incidence and yield.

\section{Result and Discussions}

Symptoms of Ethiopian pepper mottle virus characteristics including severe reduction of leaf size, curling, crinkling of interveinal areas, interveinal and marginal chlorosis, occasional development of venations, shortening of internodes, stunting or dwarfing, development of small branches, and bright yellow spot on leaves, mottle and reduced fruiting were observed in pepper experimental fields (Figure 3).

\section{Incidence of Ethiopian pepper mottle virus}

Analysis of variance indicated highly significant differ-

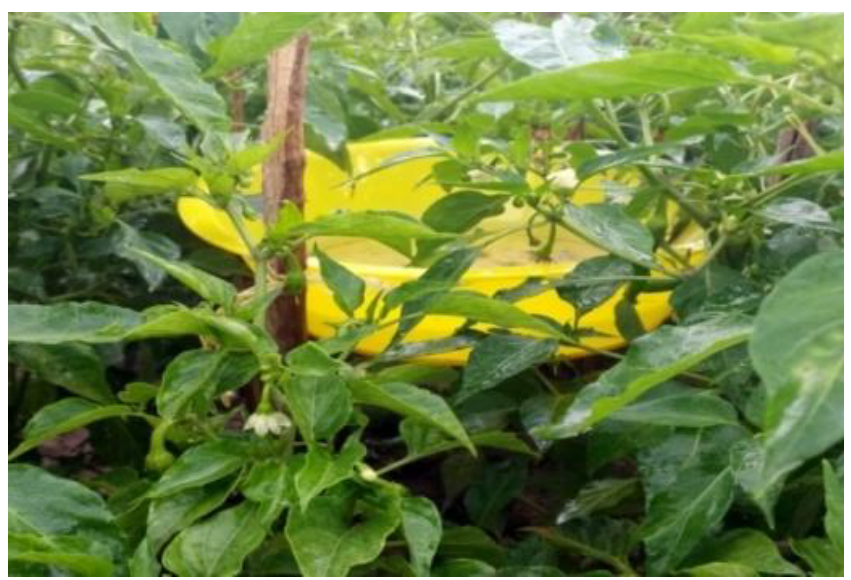

Figure 2: Aphid monitoring using yellow water trap. 

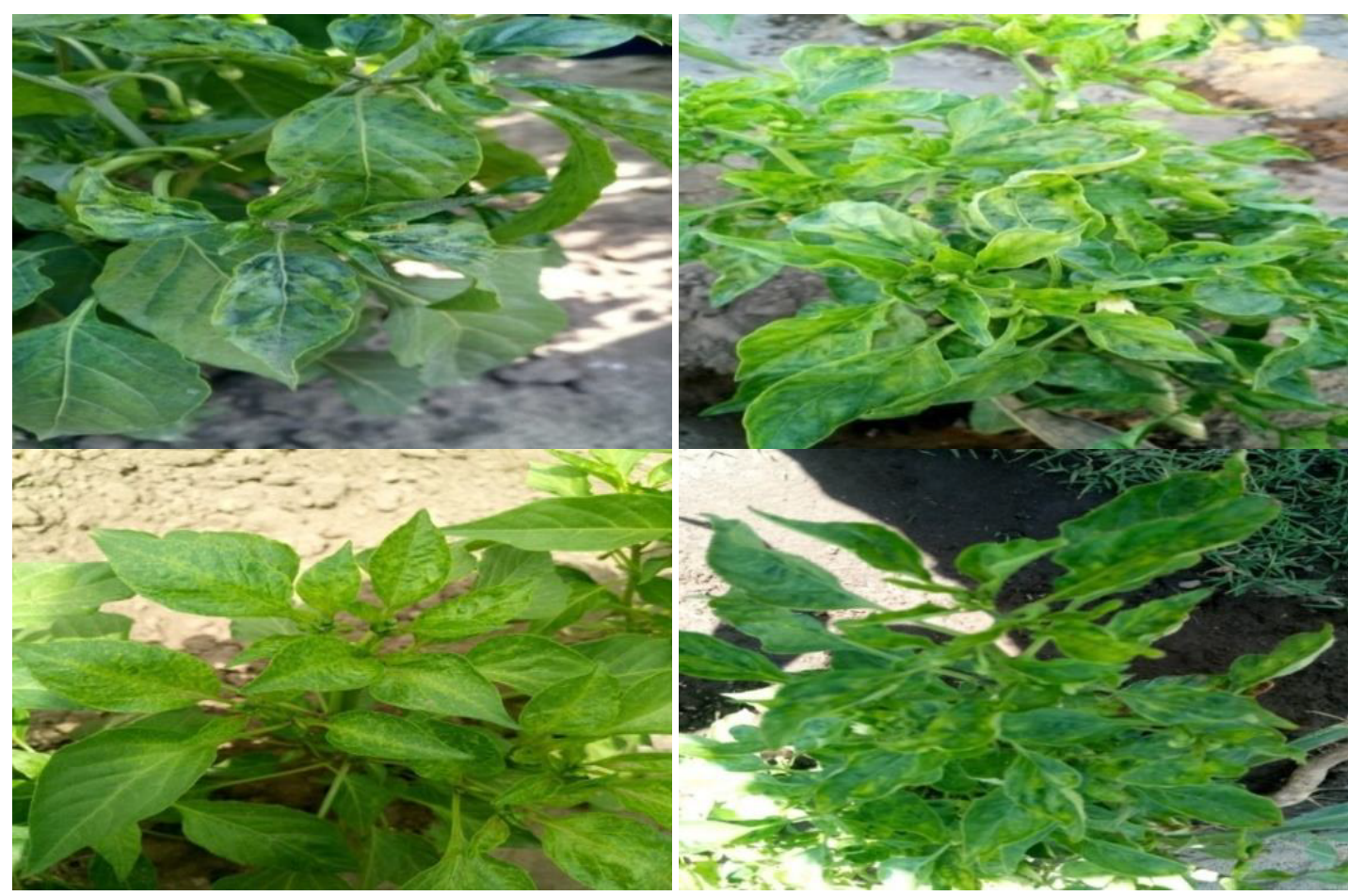

Figure 3: Pepper plants showing EPMV disease symptom.

Table 1: Effect of nets on aphids per plant, average disease incidence and final disease incidence.

\begin{tabular}{|l|l|l|l|l|l|l|}
\hline \multirow{2}{*}{ Treatment } & \multicolumn{2}{|l|}{ Aphids per plants \pm SE } & \multicolumn{2}{l|}{ Average disease incidence \pm SE } & \multicolumn{2}{l|}{ Final disease incidence \pm SE } \\
\cline { 2 - 7 } & Hawassa & Meki & Hawassa & Meki & Hawassa & Meki \\
\hline Uncovered & $40.50 \pm 1.72^{\mathrm{a}}$ & $45.21 \pm 0.91^{\mathrm{a}}$ & $57.50 \pm 1.30^{\mathrm{a}}$ & $63.12 \pm 1.19^{\mathrm{a}}$ & $81.25 \pm 2.60^{\mathrm{a}}$ & $87.50 \pm 0.50^{\mathrm{a}}$ \\
\hline Netting for up to 20 days & $27.75 \pm 1.97^{\mathrm{b}}$ & $39.37 \pm 0.34^{\mathrm{ab}}$ & $43.75 \pm 1.25^{\mathrm{ab}}$ & $52.50 \pm 1.04^{\mathrm{b}}$ & $71.87 \pm 2.12^{\mathrm{ab}}$ & $78.12 \pm 0.13^{\mathrm{ab}}$ \\
\hline Netting for up to 40 days & $17.93 \pm 0.87^{\mathrm{c}}$ & $25.90 \pm 2.06^{\mathrm{bc}}$ & $34.97 \pm 1.39^{\mathrm{bc}}$ & $42.50 \pm 1.02^{\mathrm{cd}}$ & $51.37 \pm 1.05^{\mathrm{cd}}$ & $65.62 \pm 1.10^{\mathrm{cd}}$ \\
\hline Netting for up to 60 days & $17.37 \pm 1.34^{\mathrm{c}}$ & $21.56 \pm 0.52^{\mathrm{bc}}$ & $29.87 \pm 1.83^{\mathrm{bc}}$ & $38.75 \pm 1.25^{\mathrm{de}}$ & $40.62 \pm 1.12^{\mathrm{de}}$ & $59.37 \pm 2.12^{\mathrm{d}}$ \\
\hline Netting for up to 80 days & $13.06 \pm 0.65^{\mathrm{c}}$ & $18.31 \pm 1.03^{\mathrm{c}}$ & $24.37 \pm 0.62^{\mathrm{c}}$ & $35.00 \pm 1.04^{\mathrm{de}}$ & $37.50 \pm 0.24^{\mathrm{de}}$ & $43.75 \pm 1.60^{\mathrm{e}}$ \\
\hline Netting until harvesting & $10.50 \pm 0.47^{\mathrm{c}}$ & $14.90 \pm 1.27^{\mathrm{c}}$ & $22.50 \pm 0.33^{\mathrm{c}}$ & $32.50 \pm 1.06^{\mathrm{e}}$ & $34.37 \pm 1.13^{\mathrm{e}}$ & $40.62 \pm 1.12^{\mathrm{e}}$ \\
\hline Spraying with insecticide & $30.81 \pm 0.19^{\mathrm{b}}$ & $37.37 \pm 2.71^{\mathrm{ab}}$ & $48.12 \pm 1.60^{\mathrm{ab}}$ & $49.37 \pm 1.19^{\mathrm{bc}}$ & $66.25 \pm 2.60^{\mathrm{bc}}$ & $75.00 \pm 0.25^{\mathrm{bc}}$ \\
\hline LSD (0.05) & 8.87 & 17.84 & 18.64 & 9.11 & 14.92 & 12.20 \\
\hline CV (\%) & 15.92 & 26.37 & 21.39 & 8.69 & 11.66 & 8.12 \\
\hline
\end{tabular}

Where, CV: Coefficient of variation; LSD: Least significant difference; SE: Standard error.

Means in a column followed by the same letter are not significantly different at $p<0.05$, whereas the means indicated by different letters shows significantly different.

ence in virus incidence across treatments at both locations. The lowest EPMV incidence $22.5 \%$ at Hawassa and $32.5 \%$ at Meki) was recorded from the pepper plants covered by net until harvesting (Table 1). On the other hand, the highest mean EPMV incidence $\mathbf{5 7 . 5 \%}$ in Hawassa and $63.12 \%$ in Meki) was recorded from uncovered plots. Therefore, netting until harvesting was considered the most effective in reducing viral incidence. In a previous work, Olobashola, et al. [17] reported aluminum mulching as effective measure in reducing virus incidence.

Overall disease incidence was high in Meki as compared to Hawassa. This might be due to the presence of several hosts for the vectors in and around the experimental field in
Meki. The results are consistent with the finding of DiFonzo, et al. [12] who reported rapid spreading of viruses in particular area associated with the presence of vectors and hosts. Atsebeha, et al. [11] also reported increasing of virus with a large diversity of crop species cultivated and weed species in and around field. Similarly, Nault, et al. [18] reported the infection of Cucumber Mosaic virus (CMV) in Alfalfa was greatly associated with dispersal of aphids from nearby Snap Beans.

\section{Aphid's population per plant}

Aphids were more abundant at Meki as compared to Hawassa. This might due to the presence of many hosts in and around pepper fields and environmental condition in Meki 
Citation: Dida K, Chala A, Azerefegne F (2020) Effect of Netting Duration on Ethiopian Pepper Mottle Virus (EPMV) Infection and Aphid Infestation of Hot Pepper (Capsicum annuum L.) in Central Rift Valley Region of Ethiopia. J Plant Pathol Res 2(1):6-12

area. This result agrees with DiFonzo, et al. [12] who reported the positive role of several cultivated crops and volunteer plants in increasing the population of aphids in potato farms in the same region. Similarly, Atsebeha, et al. [11] reported that population of aphid species was high in the presence of large diversity of crop species cultivated.

The mean number of aphids per plant across treatments at both locations was significantly different. Plots covered by net until harvesting and up to 80 days after transplanting were consistently significantly different from plots of other treatments in reducing the aphid population regardless of the location. On the other hand, the significance reduction in aphid population was varied depending on the location when plots were covered with nets only up to 60 days after transplanting (Table 1).

The highest mean number of aphids per plants (40.5 in Hawassa and 45.21 in Meki) was recorded from control plots while the lowest mean of aphids per plants (10.5 in Hawassa and 14.9 in Meki) was recorded from plots covered by net until harvesting. As compared to the control plots, the mean number of aphids per plant was reduced by $74 \%$ at Hawassa and $67 \%$ at Meki, when plots were covered by net until harvesting. On other hand, covering plots by net for up to 80 days after transplanting has reduced mean number of aphids per plant by $67.8 \%$ and $40.5 \%$ at Hawassa and Meki respectively, as compared to the unprotected plots (Table 1).

\section{Effect of netting duration on yield}

Marketable yield: Netting duration had a highly significant effect on marketable yield of pepper at both locations. Plots covered by net until harvesting and up to 80 days were significantly different in terms of marketable yield from plots without netting, covered by net for up to 20 days and weekly spraying with insecticide at both locations (Table 2). Highest mean marketable yield was harvested from plots covered by net until harvesting and up to 80 days followed by netting up to 60 days after transplanting. On the other hand, the lowest mean marketable yield was harvested from control plots and plots covered by net for up to 20 days after transplanting at both locations. Variation was might be due to reduction of virus infection and vectors infestation. This finding agree with Fajinmi and Odebode, et al. [19] who indicated that increased in fruit yield and quality was achieved with a reduction of diseased plant by controlling of pepper veinal mottle virus.

As compared to control plots, marketable yield was increased by $49 \%$ and $48 \%$ at Meki, $55 \%$ and $51 \%$ at Hawassa when plants were covered by net until harvesting and covered by net for up to 80 days after transplanting, respectively (Table 2). Avilla, et al. [20] also indicated 20 to $80 \%$ increase in marketable yield when plants were infected by potyvirus at latter growth stage.

Unmarketable yield: The result revealed that netting duration had a significant $(P<0.01)$ effect on the unmarketable yield. Control plots were significantly different from plots covered by net for up to 40 days and longer at Hawassa while it was significantly different from plots covered by net for up to 60 days and more at Meki (Table 2). The highest mean unmarketable yield ( $1.53 \mathrm{q} /$ ha in Meki and $1.08 \mathrm{q} /$ ha in Hawassa) was recorded from control plots. On the other hand, the lowest mean unmarketable yield ( $0.27 \mathrm{q} /$ ha in Meki and $0.11 \mathrm{q} /$ ha in Hawassa) was recorded from plots covered by nets until harvesting and covered by net for up to 80 days after transplanting, respectively (Table 2). Meyers, et al. [21] reported $50-60 \%$ yield reduction of pepper plants due to the infection of potyvirus.

In this study it was observed that unmarketable yield decreased with increasing in net cover duration. This might be due to nets protecting aphids infestation at early growth stage and physiological disorders (bleaching) during the fruit set or the climatic conditions of the growing environment. As compared to control plots, plots covering plants by nets up to 80 days after transplanting or until harvesting reduced unmarketable yields by $80-89 \%$ at Hawassa and $75-82 \%$ at Meki (Table 2). This finding was agreement with Fuchs and Minzenmayer, et al. [22] who reported greater than $25 \%$ reduction in cotton fruit yield when crops with higher incidence

Table 2: Effect of netting duration on marketable, unmarketable and total yield.

\begin{tabular}{|c|c|c|c|c|c|c|}
\hline \multirow[t]{2}{*}{ Treatments } & \multicolumn{2}{|c|}{ Marketable yield (q/ha) \ SE } & \multicolumn{2}{|c|}{ Unmarketable yield (q/ha) \pm SE } & \multicolumn{2}{|c|}{ Total yield $(q / h a) \pm S E$} \\
\hline & Hawassa & Meki & Hawassa & Meki & Hawassa & Meki \\
\hline Uncovered & $11.45 \pm 0.80^{d}$ & $10.33 \pm 0.96^{c}$ & $1.08 \pm 0.27^{a}$ & $1.53 \pm 0.24^{\mathrm{a}}$ & $12.53 \pm 0.77^{c}$ & $11.86 \pm 0.68^{c}$ \\
\hline Netting for up to 20 days & $11.99 \pm 0.49^{c d}$ & $10.75 \pm 2.07^{b c}$ & $1.06 \pm 0.18^{\mathrm{a}}$ & $1.26 \pm 0.18^{\mathrm{ab}}$ & $13.05 \pm 0.40^{c}$ & $12.01 \pm 0.89^{c}$ \\
\hline Netting for up to 40 days & $16.10 \pm 0.69^{a b c}$ & $13.10 \pm 0.87^{\mathrm{ab}}$ & $0.39 \pm 0.16^{\mathrm{ab}}$ & $1.16 \pm 0.19^{\mathrm{abc}}$ & $16.50 \pm 0.82^{a b c}$ & $14.26 \pm 0.24^{\mathrm{abc}}$ \\
\hline Netting for up to 60 days & $16.51 \pm 1.61^{\mathrm{ab}}$ & $14.26 \pm 1.93^{a}$ & $0.23 \pm 0.06^{b}$ & $0.64 \pm 0.24^{b c d}$ & $16.74 \pm 1.57^{\mathrm{abc}}$ & $14.91 \pm 0.99^{\mathrm{ab}}$ \\
\hline Netting for up to 80 days & $17.30 \pm 1.10^{\mathrm{a}}$ & $15.33 \pm 1.74^{\mathrm{a}}$ & $0.11 \pm 0.03^{b}$ & $0.37 \pm 0.14^{\text {cd }}$ & $17.42 \pm 1.08^{\mathrm{ab}}$ & $15.71 \pm 0.74^{a}$ \\
\hline Netting until harvesting & $17.75 \pm 0.92^{\mathrm{a}}$ & $15.45 \pm 2.03^{a}$ & $0.21 \pm 0.05^{b}$ & $0.27 \pm 0.11^{d}$ & $17.96 \pm 1.90^{\mathrm{a}}$ & $15.72 \pm 0.94^{a}$ \\
\hline Spraying with insecticide & $12.14 \pm 0.56^{\mathrm{bcd}}$ & $11.48 \pm 1.05^{b c}$ & $0.97 \pm 0.02^{a}$ & $1.41 \pm 0.20^{\mathrm{ab}}$ & $13.12 \pm 0.53^{b c}$ & $12.90 \pm 0.66^{b c}$ \\
\hline LSD (0.05) & 4.38 & 2.73 & 0.71 & 0.88 & 4.29 & 2.68 \\
\hline CV (\%) & 12.7 & 9.03 & 52.92 & 39.54 & 11.99 & 8.24 \\
\hline
\end{tabular}

Where, CV: Coefficient of variation; LSD: Least significant difference; SE: Standard error.

Means in a column followed by the same letter are not significantly different at $p<0.05$, whereas the means indicated by different letters shows significantly different. 
Citation: Dida K, Chala A, Azerefegne F (2020) Effect of Netting Duration on Ethiopian Pepper Mottle Virus (EPMV) Infection and Aphid Infestation of Hot Pepper (Capsicum annuum L.) in Central Rift Valley Region of Ethiopia. J Plant Pathol Res 2(1):6-12

of potyvirus. Similarly, Mukasa, et al. [23] reported up to $98 \%$ decrease in yield when sweet potato plants were infected by sweet potato feathery mottle virus at latter growth stages than early growth stages.

Total yield: Netting duration had a highly significant effect on total yield of pepper at both locations. Generally, the highest mean total yield was harvested from plots covered by net until harvesting and up to 80 days followed by covered by net for up to 60 days while the lowest total yield was harvested from plots without netting and covered by net for up to 20 days after transplanting at both locations (Table 2). This result agrees with Agrios and Walker, et al. [24] who reported increased in growth and yield when pepper plants were infected at latter growth stage.

As compared to control plants (no netting), pepper plants from plots covered by net until harvesting and up to 80 days after transplanting gave $39-43 \%$ and $32 \%$ more yield at $\mathrm{Ha}$ wassa and Meki, respectively (Table 2). Tameru, et al. [10] also reported greater than $90 \%$ yield loss and complete pepper plants failure in Ethiopia by potyvirus genus special Ethiopian pepper mottle virus and potato virus Avilla, et al. [20] found similar effects of virus on total weight and marketable weight of fruit produced by pepper plants infected at different stage of development.

\section{Correlation between disease, vectors and yield}

Correlation analysis among disease and yields revealed the negative impacts of virus on pepper quantitative and qualitative yield except unmarketable yield which was positively influenced by disease and vectors at both locations (Table 3 and Table 4). This result is in agreement with Tameru, et al. [8] who reported reduction in pepper pod yield due to potyvirus.
In general, there was positive and highly significant ( $p$ $<0.001)$ correlation between virus incidence, aphids population and unmarketable yield. This finding is in agreement with Fajinmi, et al. [25] who reported that aphids' distribution within a particular area has a significant contribution in transmitting viral diseases that subsequently lead to yield losses. Marketable yield and total yield were negatively correlated with virus incidence and aphids population at both locations (Table 3 and Table 4). Increasing disease incidences and vectors can cause significant reduction in the yields. Fajinmi and Odebode, et al. [19] reported that the yield of pepper was negatively correlated with pepper mottle virus and vectors.

\section{Conclusion}

Pepper is an important cash and spice crop in Ethiopia. It is widely cultivated in some part of Ethiopia especially in the rift valley. However, the production is affected by abiotic and biotic factors. Among biotic factors, viral disease transmitted by vectors is one of the main problem productions of pepper in the central rift valley of Ethiopia.

In Ethiopia, there is a gap in managing viral diseases of crop plants (including pepper) in a way that increases the quantitative and qualitative yield of peppers. Hence, the present study aims to contribute towards effective and sustainable management of pepper virus for improved yields. The experiment determined the role of netting cover in protecting pepper plants from pepper mottle virus and their vectors. Overall, significant increase in virus infection and aphids infestation was recorded at both experimental fields (Hawassa and Meki), when pepper plants grew without netting. This was followed by significant reduction in growth parameters (plant height, number of branches per plant and leaf canopy cover) and yield, especially marketable yield. The effect was comparable to weekly spraying with insecticide, suggesting

Table 3: Correlation among disease, vectors, growth parameter and yield at Meki.

\begin{tabular}{|l|l|l|l|l|l|l|l|l|l|}
\hline & BN & PH & LCC & POD & MY & UMY & TY & INC \\
\hline MY & $0.5599^{* *}$ & $0.6665^{* * *}$ & $0.7079^{* *}$ & $0.6064^{* * *}$ & 1 & & & \\
\hline UMY & $-0.5215^{* *}$ & $-0.6794^{* * *}$ & $-0.5536^{* *}$ & $-0.7220^{* * *}$ & $-0.7219^{* * *}$ & 1 & & \\
\hline TY & $0.5152^{* *}$ & $0.5965^{* * *}$ & $0.6817^{* *}$ & $0.5130^{* *}$ & $0.9801^{* * *}$ & $-0.5704^{* *}$ & 1 & & \\
\hline INC & $-0.5500^{* *}$ & $-0.7530^{* * *}$ & $-0.8771^{* * *}$ & $-0.7142^{* * *}$ & $-0.7957^{* *}$ & $0.6832^{* * *}$ & $-0.7487^{* * *}$ & 1 \\
\hline APH & $-0.4758^{*}$ & $-0.7772^{* * *}$ & $-0.7014^{* * *}$ & $-0.6046^{* * *}$ & $-0.5595^{* *}$ & $0.6880^{* * *}$ & $-0.4670^{*}$ & $0.5241^{* * *}$ & 1 \\
\hline
\end{tabular}

Where, ${ }^{*}=p<0.05,{ }^{* *}=p<0.01$ and ${ }^{* * *}=p<0.0001$

MY: Marketable yield; UMY: Unmarketable yield; TY: Total yield; INC: Viral incidence; APH: Aphids population per plant.

Table 4: Correlation among disease, vectors, growth parameter and yield at Hawassa.

\begin{tabular}{|l|l|l|l|l|l|l|l|l|l|}
\hline & BN & PH & LDC & POD & MY & UMY & TY & INC \\
\hline MY & $0.6877^{* * *}$ & $0.6456^{* *}$ & $0.4216^{*}$ & $0.5524^{* *}$ & 1 & & & \\
\hline UMY & $-0.6853^{* * *}$ & $-0.6406^{* *}$ & $-0.4565^{*}$ & $-0.6127^{* *}$ & $-0.7553^{* * *}$ & 1 & & \\
\hline TY & $0.6538^{* *}$ & $0.6143^{* *}$ & $0.3945^{*}$ & $0.5142^{* *}$ & $0.9933^{* * *}$ & $-0.6746^{* * *}$ & 1 & & \\
\hline INC & $-0.7332^{* * *}$ & $-0.7421^{* * *}$ & $-0.4626^{*}$ & $-0.5125^{* *}$ & $-0.7283^{* * *}$ & $0.5941^{* * *}$ & $-0.7157^{* * *}$ & 1 \\
\hline APH & $-0.7416^{* * *}$ & $-0.7757^{* * *}$ & $-0.5721^{* *}$ & $-0.5986^{* *}$ & $-0.7686^{* * *}$ & $0.7738^{* * *}$ & $-0.7294^{* * *}$ & $0.8365^{* * *}$ & 1 \\
\hline
\end{tabular}

Where $^{*}=p<0.05,{ }^{* *}=p<0.01$ and ${ }^{* * *}=p<0.001$

MY: Marketable yield; UMY: Mnmarketable yield, TY: Total yield; INC: Viral incidence; APH: Aphids population per plant. 
Citation: Dida K, Chala A, Azerefegne F (2020) Effect of Netting Duration on Ethiopian Pepper Mottle Virus (EPMV) Infection and Aphid Infestation of Hot Pepper (Capsicum annuum L.) in Central Rift Valley Region of Ethiopia. J Plant Pathol Res 2(1):6-12

the inefficiency of the applied insecticide. On the other hand, net cover up to 80 days or more significantly reduced pepper viruses and their vectors while significantly improving yield and yield component.

\section{Acknowledgment}

We thankfully acknowledge the financial grant from IPM Vegetable project and the Ministry of Education for financial support for conducting these studies.

\section{References}

1. Acquaah G (2004) Horticulture: Principles and Practices. (2 edn), Prentice Hall of India Private Ltd. New Delhi, India.

2. Berhanu Yadeta, Derbew Belew, Wosene Gebresillassie, et al. (2011) Variability, heritability and genetic advance in hot pepper (Capsicum annuum L.) genotypes in west Showa, Ethiopia. American Eurasian Journal of Agriculture and Environmental Science 10: 587-592.

3. Beyene T, David P (2007) Ensuring Small Scale Producers in Ethiopia to Achieve Sustainable and Fair Access to Pepper Market. Uganda Journal of Agriculture 3: 113-119.

4. (2004) Progress Report on Completed Activities. Melkasa Agricultural Research Center (MARC).

5. Delelegn S (2009) Evaluation of elite hot pepper varieties (capsicum species) for growth, dry pod yield and quality under Jimma condition, south west Ethiopia. Jimma University, Jimma, Ethiopia.

6. Green SK, Kim JS (1991) Characteristics and control of virus infecting pepper: A literature review. Technical Bulletin -Asian Vegetable Research and Development Center, AVRDC, Taiwan.

7. Yaynu H, Lesemann D, Vetten HJ (1999) Occurrence, distribution and relative importance of viruses infecting hot pepper and tomato in the major growing areas of Ethiopia. Journal of Phytopathology 147: 5-11.

8. Tameru A (2004) Characterization of virus of pepper (Capsicum spp.) and sweet potato (Ipomoeabatatas) from Ethiopia. University of Bonn, Gottingen, Germany.

9. Agranovsky AA (1993) Virus diseases of pepper (Capsicum annuum $L$ ) in Ethiopia. Journal of Phytopathology 138: 89-97.

10. Tameru A, Hamacher J, Dehne HW (2003) The increase in importance of Ethiopian pepper mottle Virus (EPMV) in the rift valley part of Ethiopia - Time to create awareness among farmers and researchers. Deutscher Tropentage, October 18-21, Gottingen, Germany.

11. Atsebeha S, Alemu T, Azerefegne F (2009) Diversity of aphids in the central rift valley of Ethiopia and their potential as vectors for Ethiopian Pepper Mottle Virus (EPMV). Journal of Entomology and Nematology 1: 1-6.

12. DiFonzo CD, Ragsdale DW, Radcliffe EB, et al. (1997) Seasonal abundance of aphid vectors of Potato virus $Y$ in the Red River Valley of Minnesota and North Dakota. Journal of Economic Entomology 90: 824-831.

13. Fajinmi AA, Fajinmi OB (2010) Incidence of okra mosaic virus at different growth stages of Okra plants (AbelmoschusesculentusL. Moench) under tropical condition. Journal of General and Molecular Virology 2: 28-31.

14. (2004) Released crop varieties and their recommended cultural practices. Progress report. Ethiopian Agricultural research Organization (EARO), Addis Ababa, Ethiopia.

15. Marame F, Fininsa C, Singh H, et al. (2010) Occurrence of aphid vector and genetic tolerance to infection by potyvirus in hot pepper. Euphytica 172: 85-91.

16. (2002) SAS for windows released 9.0. Statistical Analysis System (SAS), SAS institute, Inc. Cary, NC, USA.

17. Olobashola N, Salaudeen MT, Achikwu M (2017) Growth and yield Responses of Sweet Pepper (Capsicum AnnuumL.) Cultivars to Infections with Cucumber mosaic virus Disease. Nigerian Journal of Agriculture, Food and Environmental 13: 201-205.

18. Nault BA, Saha DA, Dillard HR, et al. (2004) Seasonal and spatial dynamics of alate aphid dispersal in Snap bean in proximity to alfalfa and implication for virus management. Environmental Entomology 33: 1593-1601.

19. Fajinmi AA, Odebode CA (2010) Evaluation of maize/pepper intercropping model in the management of Pepper veinal mottle virus, genus Potyvirus, family Potyviridae on cultivated pepper (Capsicum annuum L.) in Nigeria. Arch Phytopathology Plant Protection 43: 1524-1533.

20. Avilla C, Collar JL, Duque M, et al. (1997) Yield of bell pepper (Capsicum annuum) inoculated with CMV and/or PVY at different time intervals. Journal of Plant Disease Protection 104: 1-8.

21. Meyers L, Martin R, McDonald S (1998) The effect of tobacco etch virus on the growth and yield of two pepper Capsicum chinense varieties. $34^{\text {th }}$ Annual conference of the Caribbean Food Crops Society, Jamaica.

22. Fuchs TW, Minzenmayer R (1999) Effects of Aphis gossypii on cotton development and yield in west Texas. Southwestern Entomologist 20: 341-349.

23. Mukasa SB, Rubaihayo PR, Valkonen JP (2003) Incidence of viruses and virus like diseases of sweet potato in Uganda. Plant Disease 87: 329-335.

24. Agrios GN, Walker ME (2005) Effect of Cucumber mosaic virus inoculation at successive weekly intervals on growth and yield of pepper (Capsicum annuum) plants. Journal of Plant Disease 69: 52-55.

25. Fajinmi AA (2011) Agro-ecological incidence and severity of Pepper veinal mottle virus, genus Potyvirus, family Potyviridae, on cultivated pepper (Capsicum annuum L.) in Nigeria. Arch Phytopathology Plant Protection 44: 307-319.

DOI: $10.36959 / 394 / 619$

Copyright: (C) 2020 Dida K, et al. This is an open-access article distributed under the terms of the Creative Commons Attribution License, which permits unrestricted use, distribution, and reproduction in any medium, provided the original author and source are credited. 